\title{
Exploration of the Design of Entrepreneurship Training Model for Vocational College Students
}

\author{
Tingting Chen \\ Nanjing Institute of Mechatronic Technology \\ Nanjing, China 211135
}

\begin{abstract}
In recent years, with the rapid development of the market economy in China, the entrepreneurial issues of college students have been highly valued by the education department. Among them, in order to reduce the factors of failures for students to succeed in entrepreneurship, it becomes particularly important for vocational colleges to carry out entrepreneurship training. This article mainly discusses the design of entrepreneurship training model for vocational college students with the purpose of providing some references and suggestions for the entrepreneurial training model of higher vocational college students.
\end{abstract}

Keywords-vocational college; student entrepreneurship; training model; design

\section{INTRODUCTION}

In recent years, the employment competition of university students has become increasingly fierce, and the entrepreneurship of college students has increasingly attracted the attention of all sectors of society. Therefore, how to carry out entrepreneurial training activities and how to enhance students' entrepreneurial ability have become the main issue which higher vocational colleges attach importance to. The following is the design and analysis based on the entrepreneurship training model for vocational college students.

\section{REQUIREMENTS FOR THE DESIGN OF THE FOLLOWING ENTREPRENEURSHIP TRAINING MODEL FOR STUDENTS IN Higher VOCATIONAL COLLEGES}

\section{A. Adhering to the Guidance of Scientific Outlook on Development}

At present, China's social and economic development has undergone tremendous development, and the industrial structure has also changed a lot. At the same time, people's consumption consciousness is different from before. Therefore, the importance of entrepreneurship must be realized, especially in today's rapidly developing market economy. Hard work should be made to achieve the entrepreneurial dreams of young people. However, the road to entrepreneurship will not be easy and it will be full of difficulties and all kinds of dangers and uncertainties. Everyone is longing for success, but not all people can achieve this goal, especially those students who are unsophisticated. They have a wealth of knowledge but do not know how to apply it to reality. Therefore, we must teach students to comprehensively analyze and pay attention to the needs of the market during the process of entrepreneurship, take into account the various uncertainties that may arise during the period and formulate and improve the solution, to make the greatest efforts to succeed in the entrepreneurship and get approval from all walks of life.

\section{B. Combination of Entrepreneurship Training Model and Enterprise Training Model}

In the process of designing the entrepreneurship training model, we must pay attention to the integration between the training model and the enterprise. Therefore, in the enterprise training mode, we must carry out the necessary discussion and research to find out the important characteristics of enterprise training, such the level, universality, and persistence of corporate training. In addition, we must also pay attention to the other important point of corporate training, namely practicality. We should focus on the study of these characteristics of corporate training, and then integrate it with the entrepreneurial training model to provide the necessary guarantees for the timeliness and effectiveness of the entrepreneurship training model.

\section{Taking University Training as an Important Support}

In terms of entrepreneurship training, colleges and universities have great advantages. For example, colleges and universities have high-level education faculty, which provides a solid theoretical foundation for the design of entrepreneurship training for higher vocational college students, but we still need to pay attention that although universities have certain advantages in training, there are also other problems, such as lack of practical experience. Therefore, in order to improve this problem, higher vocational colleges can employ some experts and scholars with rich experience in the training design to provide coaching for the design of entrepreneurial model training for teachers and students. On the basis of guaranteeing training theories, important vocational training will be conducted in order to combine practice and theory so that entrepreneurial training can be implemented and improved as soon as possible. 


\section{Fully Understanding the Personality Characteristics of College Students}

In the process of designing the entrepreneurial training model, it is necessary to pay attention to the overall understanding of the students, to see the bright spots of different students, and to carry out design work based on these characteristics, achieving "people-oriented". Therefore, the teacher should pay attention to fully understanding the students' personality and characteristics and becoming familiar with their hobbies. Nowadays, with the everincreasing development of the times, the personality characteristics of college students have become even more obvious. They are mainly manifested in the fact that their propensity to choose a career is different from that of others, so that they can demonstrate their unique characteristics and achieve the purpose of obtaining respect and recognition from others [1].

\section{The Design of Vocational College Students' ENTREPRENEURSHIP TRAINING MODEL}

\section{A. The Design Rules of the Model of Real Competition for Risk Fund}

The design of the rules for risk fund model is an important foundation for ensuring the students' real competing for the risk model. The main method of operation is that each student must hand over a certain amount of risk fund. For example, students can use their own pocket money as risk fund, and then set up different types of professional teams based on this. However, before the team created by students conduct entrepreneurial activities, vocational colleges should do a good job in training them in order to reduce the risk of their failure in entrepreneurship. For example, before students start a business, school should require students to conduct relevant information investigations, and write a practical plan based on the results obtained, and then carry out real competition activities. For the teams that win in the real competition, they can be awarded the title of their excellent team and be given a certain material reward to inspire their entrepreneurial awareness.

\section{B. The Design Process of Real Competition for Risk Fund}

In the process of training of real competition for risk fund, the instructor will spend a certain amount of time imparting the theoretical knowledge to all students and pass on the experience of successful entrepreneurship, and then they enter the project stage. Students can make fast evaluation form for the feasibility of in-depth study, and thus understand how to properly select the appropriate project. After the introduction of the plan, all entrepreneurial students will conduct orderly simulation activities in accordance with the requirements of the process, and make corresponding evaluations after communicating with each team. Then the students conduct a market survey for the entrepreneurial project for a period of time, and fill in the report according to the materials obtained from the survey.
After completing the above processes, a second training activity will be conducted. Each entrepreneurial team shall publicly display the content of the report and financial status and then the teacher and the student will score it to get the results of the retest which will account for $70 \%$ of the total score. In these two training activities, students can achieve a huge harvest. Especially the first real competition is quite beneficial to students, and the arrange is more reasonable in terms of time, but the following market survey is very demanding on the entrepreneurial team, which can create a good competitive environment for the second activity [2].

\section{SUGGESTIONS ON ENTREPRENEURSHIP TRAINING IN HIGHER VOCATIONAL SCHOOLS}

\section{A. To Strengthen the Construction of Teachers}

At present, in terms of cultivating students' entrepreneurship, colleges and universities have a shortage of teachers and the overall quality of teachers is not particularly high, which has imposed great restrictions on the promotion of entrepreneurial training models. To cultivate outstanding entrepreneurial talents, higher vocational schools must have a strong faculty, and teachers should have the following capabilities: (1) the means of innovation (2) the spirit of innovation (3) innovative technology (4) innovative mind. Since most teachers in China's higher vocational colleges are professional and technical talents, it is difficult for them to transform. Therefore, in order to give students better entrepreneurial training, colleges can select some outstanding teachers to study professional theory in professional training institutions, and allow these outstanding teachers to carry out practical activities in society. This will enable the teacher's knowledge literacy in entrepreneurship to be boosted rapidly. On the other hand, we can hire successful and experienced experts, scholars, and corporate management personnel as teachers in higher vocational schools, so that they can explain their own successful experiences and matters that should be noted during the entrepreneurial process, in order to reduce the risk rate of failure in students' entrepreneurship and let students to avoid detours as much as possible.

\section{B. To Promote Entrepreneurship Training Practices}

In entrepreneurship training in higher vocational schools, we can divide it into the following points: (1) campus practice (2) off-campus practice. From the perspective of entrepreneurship, entrepreneurship requires a certain amount of funds and a certain degree of risk. However, students do not have a lot of funds and they cannot afford huge risks. Therefore, if students want to start a business, they can only fumble in practice. After a few years of work, when they have a certain amount of capital and social experience, it is much easier to start a business since they have had much experience and the failure rate will be greatly reduced. In short, the higher vocational schools should enhance students' social experience when conducting the entrepreneurial training model to make them master the basic business process, so as to cultivate more successful talents. For example, entrepreneurship education emphasizes close 
integration with social practice, and the cooperation model between school and enterprise is an important method to achieve this goal. Therefore, in the entrepreneurial training, we must keep in mind the Scientific Outlook on Development, and use it as a guide, to strengthen the construction of the teaching staff, and take certain incentives. At the same time, we shouldn't forget to make appropriate adjustments to the model of real competition for risk fund. For example, schools can often organize seminars to teach students who want to start a business. In addition, schools can also regularly organize students to participate in entrepreneurial training activities on a voluntary basis, and then employ experienced successful people to conduct a full range of teaching in order to facilitate the smooth development of entrepreneurial training [3].

\section{CONCLUSION}

The design of the student entrepreneurship training model developed in higher vocational colleges is of inestimable importance in the student's future entrepreneurship and development, which is related to the successful implementation of student entrepreneurship training and is an important guarantee for student entrepreneurial training. Therefore, higher vocational colleges should pay high attention to the design work of entrepreneurship training model and carry out active discussion and practice. This lays a solid foundation for the smooth implementation of entrepreneurial training model design work.

\section{REFERENCES}

[1] Yang Ping. Research on Adult Entrepreneurship Training in Higher Vocational Colleges[J]. Journal of Changzhou Vocational College of Information, 2017(5):14-17. 杨萍,YANGPing. 高职院校开展成人创 业培训研究[J]. 《常州信息职业技术学院学报》,2017(5):14-17.

[2] Cheng Shuhua. Research on the Training Program of Innovation and Entrepreneurship Teachers in Higher Vocational Colleges[J]. Science and Technology \& Innovation, 2017(23):10-12. 程淑华. 高职院校创 新创业师资培训方案研究[J].《科技与创新》,2017(23):10-12.

[3] Qian Tianyi. A Preliminary Study on the Model of Diversified Cooperation and Entrepreneurship Training - An Analysis of the Case of "College Student Entrepreneurship Training Base of Zhejiang Fashion Institute of Technology" [J]. Knowledge Economy, 2017(21):136-137. 钱天一. 多元合作型创业培训模式初探—— “浙江纺织服装职业技术学院学生创业培训基地” 实例剖析 [J]. 《知识经济》,2017(21):136-137. 